\title{
Genetic assessment of the reproductive success of Atlantic salmon precocious parr by means of VNTR loci
}

\author{
PALOMA MORÁN*, A. M. PENDÁS, E. BEALL† \& E. GARCÍA-VÁZQUEZ \\ Departamento Biologia Funcional (Genetica), Universidad de Oviedo, 33006-Oviedo, Spain and $\dagger$ Ecologie des \\ Poissons, INRA Station d'Hydrobiologie, St Pée-sur-Nivelle, France
}

\begin{abstract}
Atlantic salmon precocious parr are dwarf mature males able to mate with adult females making profit of their small size. In this work the reproductive success of the dwarf males in the presence of an adult male and female spawning couple has been estimated in three different situations under simulated natural conditions at the Lapitxuri experimental channel (France). Different hypervariable minisatellite loci were used in the paternity assessment of the progeny. In all the situations tested, precocious parr were able to fertilize between 24.7 and 89.3 per cent of the total eggs. The results are discussed in relation to the important role of Atlantic salmon precocious parr in population structure and the evolution of salmon populations.
\end{abstract}

Keywords: effective population size, minisatellite loci, paternity assessment, precocious parr, reproductive success, Salmo salar.

\section{Introduction}

The spawning population of Atlantic salmon (Salmo salar L.) is composed of returning adults (anadromous salmon) and precocious male parr. As in other anadromous salmonids, Atlantic salmon males may become sexually mature before migrating to the sea (Meerburg, 1986) whereas female maturation at this stage is rare (Prouzet, 1981). The percentage of male parr that reach maturity during the first and second year of life can reach as high a value as 80 per cent in many Atlantic salmon populations (Myers, 1984).

It is well established that mature male parr take part in spawning (Jones \& King, 1952). Although they seem unable to stimulate large females to spawn because of their small size (Jones, 1959), they can place themselves in the depression generated beneath the female when shedding the eggs, and therefore fertilize part of them. This particular spawning behaviour has led them to be called 'sneakers' and is responsible for frequent severe injuries caused by attacks of large anadromous males (Hutchings \& Myers, 1988).

*Correspondence.
It is also known that mature parr produce relatively more sperm than adult males (Thorpe \& Morgan, 1980), and this fact is commonly used to fertilize eggs under artificial hatchery conditions. In naturally reproducing populations, mature parr play an important role in maintaining the genetic variability by increasing the effective size of the populations (L'Abee-Lund, 1989). The reproductive success of these individuals can only be measured by means of suitable genetic markers, such as the $M D H-4^{*}$ (Hutchings \& Myers, 1988) and MEP-2* loci (Jordan \& Youngson, 1992). However, as Atlantic salmon show very low biochemical polymorphism (Davidson et al., 1989), it has not been possible to measure accurately the precise contribution of salmon male parr under natural conditions.

The discovery that tandemly repeated DNA sequences often show a high polymorphism for the copy number of the repeating unit (Jeffreys et al., 1985) has led to the appearance of novel generations of DNA markers (i.e. mini- or microsatellites). This genetic variability has found a ready use in forensic science (Gill et al., 1985), paternity testing (Debenham, 1992), and parentage and pedigree analysis, in a wide range of animal species (reviewed in Burke, 1989). However, Atlantic salmon (and salmonids in general) multilocus profiles provide extremely 
complex patterns (Taggart \& Ferguson, 1990a) which have proven to be of small value in paternity assays. Recently, the isolation of single locus minisatellite loci from Atlantic salmon (Taggart \& Ferguson, 1990b; Prodöhl et al., 1994a) has enabled the identification of single individuals, thus providing advantages over classical markers such as isozymes and mitochondrial DNA, where the most frequent polymorphisms found are associated with diallelic loci.

In this work, we report the results of a study in which single locus minisatellite DNA markers were employed to examine the reproductive success of Atlantic salmon mature parr in conjunction with large male and female couples under simulated natural conditions.

\section{Materials and methods}

\section{Biological samples}

All the field experiments described herein were carried out in December 1992 at the Lapitxuri experimental channel at the INRA hydrobiological station (St Pée sur Nivelle, France). In this channel, river conditions are faithfully reproduced, the only difference from nature being the absence of predation.

All the fish used in the experiment were electrofished in the river Nivelle during November 1992, and maintained in the hatchery nearby the experimental channel until required for the experiment.

The experimental situation was planned in collaboration with Dr T. Burke (University of Leicester, UK). Three sections of the channel were employed in the experiment, each of them containing one returning Atlantic salmon adult couple. The number of precocious parr added to each of these sections (A, B and C) was 1, 6 and 12, respectively. Direct observation of the channel allowed us to ensure that reproduction took place as it would in the river.

The progeny were analysed at the stage of alevins (first dispersal after yolk sac reabsorption).

\section{DNA analysis}

From adult fish and their progeny DNA was obtained from white muscle, preserved in absolute ethanol, and extracted using the protocol described in Taggart et al., 1992. Four micrograms of total

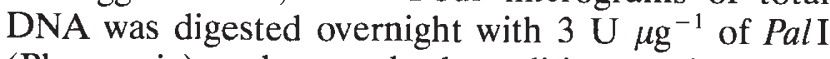
(Pharmacia) under standard conditions and electrophoresed through 0.7 per cent agarose gels for $26 \mathrm{~h}$ at 50 volts in $1 \times$ TAE buffer (Sambrook et al., 1989). DNA was transferred from the gels onto Nylon membranes (Amersham) by Southern blotting and fixed for $2 \mathrm{~h}$ at $80^{\circ} \mathrm{C}$.

Six Salmo salar minisatellite single locus probes (SLPs) (Taggart \& Ferguson, 1990b) were used. These SLPs provided one or two allele bands per individual in Pal 1 genomic Southern analyses (arbitrarily designated with a capital letter), their Mendelian inheritance having been previously tested in several families (Taggart \& Ferguson, 1990b; Prodöhl et al., 1994b). Radiolabelling, hybridization and posthybridization washes followed those described in Taggart \& Ferguson (1990b) and Pendás et al. (1994). Membranes were exposed for two days to Kodak X-Omat film at $-80^{\circ} \mathrm{C}$ with two intensifying screens.

Assignment of paternity was determined directly by comparing the molecular weight of the different alleles of the progeny with those of their mother and putative fathers. Paternity can be assigned on the basis of the presence of alleles exclusive to one of the fathers or by diagnostic allelic combinations for the different probes screened.

\section{Results}

Male and female anadromous salmon spawned successfully in the presence of mature parr under the experimental conditions described in the present work. All the parameters recorded showed that spawning took place in similar circumstances to those found in the main river.

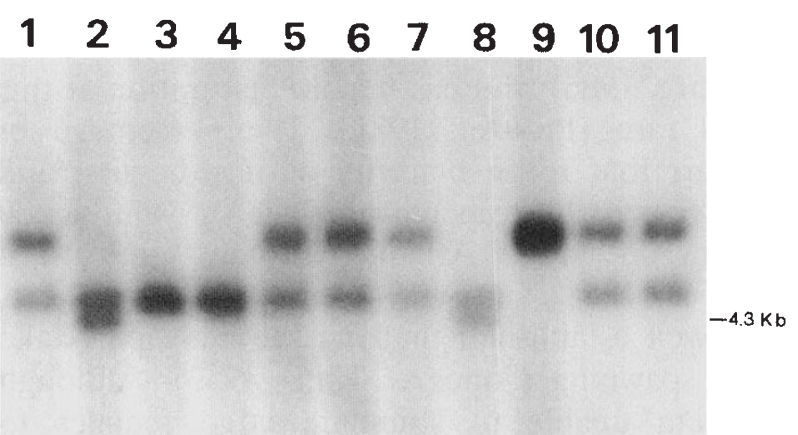

Fig. 1 Progeny identification with the hypervariable single locus probe pStr-A22/1 in section A. Lanes 9 and 3 represent the large adult male (homozygous $B B$ ) and female (homozygous $A A$ ) and lane 8 represents the male precocious parr (heterozygous $A C$ ). Lanes $1,5,6,7,10$ and 11 represent the adult male and female offspring (heterozygous $A B$ ) and lanes 2 and 4 show descendants of the female and the male precocious parr (heterozygous $A C$ and homozygous $A A$ ). 
A total number of 281 alevins were sampled from the experimental channel to determine their paternity by means of DNA fingerprint analysis. All of the fish studied showed a simple pattern (one or two bands) for all the single locus probes assayed. DNA analysis with one of the SLPs (pStr-A22/1) clearly demonstrated that precocious parr mating took place successfully in the three sections of the channel independently of the number of precocious parr employed. To evaluate more accurately the participation of the dwarf males in the different situations, every individual of the progeny was screened with four different minisatellite probes.
Figure 1 shows an example of progeny identification in section $\mathrm{A}$ using probe $\mathrm{pStr}-\mathrm{A} 22$. In this cross, the female was homozygous for the allele $A$ and the large male was homozygous $B B$, whereas the precocious male parr involved turned out to be an $A C$ heterozygote. The use of this probe therefore makes it possible to assign paternity unequivocally to the unique dwarf present ( 23 of 93 alevins) or to the adult male. The participation of the parr in section $\mathrm{A}$, in terms of percentage progeny, was calculated by this procedure to be 24.73 per cent. The participation of the precocious parr in the other two sections are shown in Tables 1 (section B) and 2 (section $\mathrm{C}$ ).

Table 1 Single locus analyses for the four minisatellites examined among 94 alevins in section B. Progeny refers to the number of parr that can be assigned to one of the putative fathers by the presence of exclusive alleles or the allelic combinations of the different probes screened

\begin{tabular}{|c|c|c|c|c|c|}
\hline \multirow[b]{2}{*}{ Individual } & \multicolumn{4}{|c|}{ Probe } & \multirow[b]{2}{*}{ Progeny } \\
\hline & $\mathrm{p} S s a-\mathrm{A} 45 / 1$ & $\mathrm{pStr}-\mathrm{A} 22 / 1$ & $\mathrm{p} S s a-\mathrm{A} 60$ & $\mathrm{pStr}-\mathrm{A} 5$ & \\
\hline Adult female & $\mathrm{AB}$ & $\mathrm{BC}$ & $\mathrm{BC}$ & $\mathrm{AB}$ & \\
\hline Adult male & $\mathrm{CD}$ & $\mathrm{CD}$ & $\mathrm{AC}$ & $\mathrm{CE}$ & 10 \\
\hline Prec. 1 & $\mathrm{BD}$ & $\mathrm{BE}$ & $\mathrm{AC}$ & $\mathrm{AD}$ & 3 \\
\hline Prec. 2 & $\mathrm{AC}$ & $\mathrm{AC}$ & $\mathrm{BC}$ & $\mathrm{AD}$ & 8 \\
\hline Prec. 3 & $\mathrm{BF}$ & $\mathrm{AC}$ & $\mathrm{CC}$ & AA & - \\
\hline Prec. 4 & $\mathrm{CB}$ & $\mathrm{AB}$ & $\mathrm{BC}$ & $\mathrm{AD}$ & 4 \\
\hline Prec. 5 & CG & $\mathrm{AB}$ & $\mathrm{CD}$ & BD & 3 \\
\hline Prec. 6 & $\mathrm{AE}$ & $\mathrm{BC}$ & $\mathrm{CE}$ & $\mathrm{AD}$ & 2 \\
\hline
\end{tabular}

Table 2 Single locus analyses for the four minisatellites examined among 94 alevins in section C. Progeny refers to the number of parr that can be assigned to one of the putative fathers by the presence of exclusive alleles or the allelic combinations of the different probes screened

\begin{tabular}{|c|c|c|c|c|c|}
\hline \multirow[b]{2}{*}{ Individual } & \multicolumn{4}{|c|}{ Probe } & \multirow[b]{2}{*}{ Progeny } \\
\hline & $\mathrm{p} S s a-\mathrm{A} 45 / 1$ & $\mathrm{pSs} a-\mathrm{A} 45 / 2$ & $\mathrm{p} S t r-\mathrm{A} 22 / 1$ & $\mathrm{p} S s a-\mathrm{A} 60$ & \\
\hline Adult female & $\mathrm{BC}$ & AA & $\mathrm{AB}$ & $\mathrm{AC}$ & \\
\hline Adult male & $\mathrm{AC}$ & $\mathrm{BC}$ & $\mathrm{DE}$ & AA & 52 \\
\hline Prec. 1 & BG & AA & $\mathrm{BF}$ & $\mathrm{AD}$ & 2 \\
\hline Prec. 2 & $\mathrm{BB}$ & $\mathrm{AD}$ & $\mathrm{CD}$ & $\mathrm{BD}$ & 3 \\
\hline Prec. 3 & BG & $\mathrm{AA}$ & $\mathrm{BC}$ & $\mathrm{AB}$ & 2 \\
\hline Prec. 4 & $\mathrm{BE}$ & $\mathrm{CE}$ & $\mathrm{CC}$ & $\mathrm{CC}$ & 1 \\
\hline Prec. 5 & CG & $\mathrm{AD}$ & $\mathrm{CC}$ & $\mathrm{AC}$ & 2 \\
\hline Prec. 6 & $\mathrm{CF}$ & $\mathrm{CC}$ & $\mathrm{CE}$ & BB & 4 \\
\hline Prec. 7 & CG & DD & DE & $\mathrm{CC}$ & 1 \\
\hline Prec. 8 & BB & DD & DE & $\mathrm{AC}$ & 1 \\
\hline Prec. 9 & BG & $\mathrm{AC}$ & DH & $\mathrm{BC}$ & 4 \\
\hline Prec. 10 & FG & $\mathrm{AC}$ & $\mathrm{CE}$ & $\mathrm{AC}$ & 6 \\
\hline Prec. 11 & $\mathrm{BD}$ & AA & $\mathrm{BC}$ & $\mathrm{CF}$ & 4 \\
\hline Prec. 12 & CF & DC & $\mathrm{CE}$ & $\mathrm{CD}$ & 7 \\
\hline
\end{tabular}


In section $C, 52$ of the 94 alevins analysed were assigned to the large male by the combination of the results obtained with the probes pSsa-A45/1, pSsaA45/2, pStr-A22/1 and pSsa-A60. This leads to a total contribution of the 12 precocious parr in 39.36 per cent of the progeny and allows us to confirm the effective participation of all the parr. By this procedure, we have tried to determine the individual participation of each of the 12 precocious parr, the results ranging from 7.4 per cent participation for parr number 12 to 1.05 per cent for parr numbers 4 , 7 and 8. These values, however, are only approximate as five of the alevins could be potentially assigned to two or three precocious parr.

The precocious contribution in section B determined using probes pSsa-45/1, pStr-A22/1, pSsa-A60 and pStr-A5 was 89.36 per cent (Table 1). From these results 84 of the 94 progeny were undoubtedly assigned to dwarf males whereas the remaining ten were assigned to the adult male. In this section, it was not possible to measure the individual participation of the six putative dwarf fathers because of allele sharing. However, it was possible to demonstrate the participation of at least five of the six parr.

\section{Discussion}

The advent of DNA fingerprinting through VNTR loci has facilitated the investigation of the reproductive success and breeding behaviour of many animal species (Burke et al., 1991; Schartl et al., 1993). These highly polymorphic loci provide a simple and easily interpretable way of identifying parents and their progenies (Burke, 1989).

In this work we have evaluated the contribution of Atlantic salmon precocious parr to the progeny of an individual redd. This assessment is usually problematic because of the scarcity of polymorphic markers detected in Atlantic salmon, either using standard electrophoretic markers (isozymes) or DNA molecular techniques (RFLPs), and because of the difficulty in performing controlled experiments under natural conditions. The first drawback was overcome by the use of hypervariable single locus probes (SLPs) in the paternity screening of the progeny. The high number of alleles detected per locus allowed us to select parental fish solely on the basis of maturation stage, thus avoiding previous management, genotyping and selection of individuals suitable to perform the crosses. This represents an important advantage as the lack of sufficient individuals at the same maturation stage often represents a real handicap in many fish experiments. The other difficulty was solved by performing the experiment at the Lapitxuri channel, where natural river situations are faithfully simulated, as has been demonstrated by several experiments (E. Beall, unpublished data).

In all the simulated conditions involving precocious parr with an adult salmon couple, dwarf males were able to fertilize eggs from the adult female. Moreover, it was possible to demonstrate the participation of 18 of the 19 precocious parr employed. The lowest value for the reproductive contribution of these mature parr, in the present work, was obtained in the case when only one parr was present (24.73 per cent). This value is close to the upper limit (28 per cent) estimated by other authors (Hutchings \& Myers, 1988; Jordan \& Youngson, 1992), also under seminatural conditions, but without the possibility of controlling the ratio between adults and dwarf males. However, the reproductive contributions of the mature parr in sections B2 and B3 (39.36 per cent and 89.36 per cent) exceed those previously reported by other authors. This fact might be explained by the absence of competing adult males in the three experimental sections. Under natural conditions, when more than one anadromous male is interested in the same female, these large males would chase parr swimming in the vicinity of the female and thus the number of parr near to the redd would decrease (Myers \& Hutchings, 1987). Furthermore, the risk of the precocious parr being buried seems to pose an additional cost for 'sneaking' (Saegrov \& Urdal, 1993).

The high reproductive contribution of precocious parr in section B must not be regarded only as the largest dwarf male contribution in this experiment but also as the possible scenario in some wild natural situations. In these cases, adult males can be responsible for stimulating the female but, as a result of fertility problems such as over-maturation or lack of sperm viability (a frequent problem under hatchery conditions), they are not responsible for actual fertilization and thus most of the offspring are the progeny of dwarf males. This last point also highlights the fact that, without the availability of appropriate genetic markers, erroneous conclusions may be obtained from the theoretical expectation that most of the progeny belong to the large male. Hence, these experiments, together with additional data, continue to stress the importance of precocious parr in the Atlantic salmon life cycle (Saunders \& Schom, 1985).

The reproductive contribution of precocious parr to the population structure and evolution of Atlantic salmon populations has been virtually ignored in 
demographic models (Myers, 1984). Therefore, although it is not possible to make reliable quantitative computations of the precocious parr contribution in salmon populations, special attention should be given to their role in two main areas.

In the first instance, these precocious parr contribute to an increase in the effective population size compared with estimates based solely on large individuals (L'Abée-Lund, 1989). This fact is of special importance in populations drastically reduced by anthropogenic activities such as contamination and overexploitation, resulting in the loss of genetic variation through genetic drift. The possible large contribution of precocious parr could also help to explain why the levels of heterozygosity, measured through SLP variation, in populations restricted to fewer than 20 couples of returning salmon per year are the same order of magnitude as those found in rivers supporting more than 200 couples (Morán, 1993). Therefore, precocious parr might be important with respect to long-term viability by bringing the reproductive population size above the minimum needed for continued existence.

The second area is related to the levels of gene flow among populations in different rivers. Atlantic salmon populations are geographically structured because of the homing instinct which causes individuals to return to their natal river for spawning (Stahl, 1987). However, physical tagging experiments show measurable straying rates between rivers that would increase the gene flow and would prevent population differentiation. The consequences of straying can, however, be drastically altered by the reproductive success of precocious parr. Firstly, gene flow is reduced as a result of its indirect relationship to the increase of the effective population size, and secondly, mature parr can not naturally move between river systems, therefore contributing to the preservation of the genetic structure of a particular river.

Precocious parr reproductive success raises the question of the consequences of farmed escapes and the introduction of non-native salmon to natural populations. On this basis, it would not be necessary to wait for the returning adults (two or more years) as genetic hybridization can occur rapidly in the first year. Negative consequences of introducing foreign genomes into natural populations have been extensively reported (e.g. Hindar et al., 1991; Utter, 1991), the conclusions being related to the reduction in size of the populations and to the loss of local adaptations.

The data presented here support the importance of precocious parr as a first strategy for alternative reproduction in the Atlantic salmon life cycle and highlights their role in the genetic structure of Atlantic salmon populations.

\section{Acknowledgements}

We thank Dr J. Taggart, Dr P. Prodöhl and Dr A. Ferguson (The Queen's University of Belfast) for kindly supplying the SLPs. We are indebted to Dr T. Burke for planning the experiment, and to Dr D. F. Thomaz for his collaboration in conducting the experiment and performing field tasks. P. Morán and A. M. Pendás are in receipt of a Research Fellowship from EC AIR1-3003-92-0719. This study was supported by DGICYT PB91-0673 and UE94-0020.

\section{References}

BURKE, T. 1989. DNA fingerprinting and other methods for the study of mating success. Trends Ecol. Evol., 4, $139-144$.

BURKE, T., DOLF, G., JEFFREYS, A. AND WOLFF, R. 1991. DNA Fingerprinting: Approaches and Applications. Birkhäuser Verlag, Basel.

DAVIDSON, W. S., BIRT, T. P. AND GREen, J. M. 1989. A review of genetic variability in Atlantic salmon, Salmo salar L., and its importance for stock identification, enhancement programmes and aquaculture. J. Fish Biol., 34, 547-560.

DEBENHAM, P. G. 1992. Probing identity: the changing face of DNA fingerprinting. TIBTECH, 10, 96-102.

GILL, P., JEFFREYS, A. J. AND WERRETT, D. J. 1985. Forensic application of DNA 'fingerprints'. Nature, 318, 577--579.

HINDAR, K., RYMAN, N. AND UTTER, F. M. 1991. Genetic effects of aquaculture on natural fish populations. Aquaculture, 98, 259-261.

HUTCHINGS, J. A. AND MYERS, R. A. 1988. Mating success of alternative maturation phenotypes in male Atlantic salmon, Salmo salar L. Oecologia, 75, 169-174.

JEFFREYS, A. J., WILSON, v. AND THEIN, S. L. 1985. Hypervariable 'minisatellite' regions in human DNA. Nature, 314, 67-73.

JONES, J. w. 1959. The Salmon. Collins, London.

JONES, J. W. AND KING, G. M. 1952. The spawning of the male salmon parr (Salmon salar L.) Proc. Zool. Soc. Lond., 122, 515-619.

JORDAN, W. C. AND YOUNGSON, A. F. 1992. The use of genetic marking to assess the reproductive success of mature male Atlantic salmon parr (Salmo salar L.) under natural spawning conditions. J. Fish Biol., 41, 613-618.

L'ABÉE-LUND, J. H. 1989. Significance of mature male parr in a small population of Atlantic salmon (Salmo salar). Can. J. Fish. Aquat. Sci., 46, 928-931.

MEERBuRG, D. J. (ed.) 1986. Salmonid age at maturity. Can Sp. Publ. Fish. Aquat. Sci., 89, 118 pp. 
MORAn, P. 1993. Poblaciones de Salmonidos (Salmo salar y Salmo trutta) de Ríos Aturianos: Efectos Genéticos de las Repoblaciones. Ph.D. Thesis, Universidad de Oviedo, Spain.

MYERS, R. A. 1984. Demographic consequences of precocius maturation of Atlantic salmon (Salmo salar). Can. J. Fish. Aquat. Sci., 41, 1349-1353.

MYERS, R. A. AND HUTCHINGs, J. A. 1987. Mating of anadromous Atlantic salmon, Salmo salar L., with mature male parr. J. Fish Biol., 31, 143-146.

PENDÁs, A. M., MORÁN, P. AND GARCÍA-VÁZqUEZ, E. 1994. Organization and chromosomal location of the major histone cluster in brown trout, Atlantic salmon and rainbow trout. Chromosoma, 103, 147-152.

PRODÖHL, P. A., TAGGART, J. B. AND FERGUSON, A. 1994a. Cloning of highly variable minisatellite DNA singlelocus probes for brown trout (Salmo trutta L.) from a phagemid library. In: Beaumont, A. R. (ed.) Genetics and Evolution of Aquatic Organisms, pp. 263-270. Chapman and Hall, London.

PRODÖHL, P. A., TAGgART, J. B. AND FERGuson, A. 1994b. Single locus inheritance and joint segregation analysis of minisatellite (VNTR) DNA loci in brown trout (Salmo trutta L.). Heredity, 73, 556-566.

PRouzet, P. 1981. Observation d'une femelle de tacon de saumon Atlantique (Salmo salar L.) parvenue a maturite sexuelle en riviere. Bull. Francais Psciculture, 282, 16-19.

SAMBROOK, J., FRITCH, E. F. AND MANIATIS, T. 1989. Molecular Cloning. A Laboratory Manual. Cold Spring Harbor Laboratory Press, New York.
SAUNDERS, R. L. AND SCHOM, C. B. 1985. Importance of the variation of life history parameters of Atlantic salmon (Salmo salar). Can. J. Fish. Aquat. Sci., 42, 615-618.

SAEgRov, H. AND URdAL, K. 1993. Mature parr buried among egg in an Atlantic salmon redd. J. Fish. Biol., 43, $490-491$.

SCHARTL, M., ERBELDING-DENK, C., HÖLTER, S., NANDA, I., SCHMID, M., SCHRÖDER, J. H. AND EPPLEN, J. T. 1993. Reproductive failure of dominant males in the poeciliid fish Limia perugiae determined by DNA fingerprinting. Proc. Natl. Acad. Sci. U.S.A., 90, 7064-7068.

stahl, G. 1987. Genetic population structure of Atlantic salmon. In: Ryman, N. and Utter, F. M. (eds) Population Genetics and Fishery Management, pp. 121-140. University of Washington Press, Seattle.

TAGGART, J. B. AND FERGUSON, A. 1990a. Minisatellite DNA fingerprints of salmonid fishes. Anim. Genet., 21, 377-389.

TAggart, J. B. AND FERguson, A. 1990b. Hypervariable minisatellite DNA single locus probes for the Atlantic salmon, Salmo salar L. J. Fish Biol., 37, 991-993.

TAGGART, J. B., HYNES, R. A., PRODÖHL, P. A. AND FERGUSON, A. 1992. A simplified protocol for routine total DNA isolation from salmonid fishes. J. Fish Biol., 40, 963-965.

THORPE, J. E. AND MORGAN, R. I. G. 1980. Growth rate and smolting rate of progeny of male Atlantic saimon parr, Salmo salar L. J. Fish Biol., 17, 451-460.

UTTER, F. M. 1991. Biochemical genetics and fishery management: an historical perspective. J. Fish Biol., 39, $1-21$. 